\title{
A COMPARABILITY OF INFORMATION IN THE FINANCIAL STATEMENTS OF GAMING COMPANIES
}

\section{Malgorzata Czerny}

Poznan University of Economics and Business, Poznan, Poland

e-mail: malgorzata.czerny@ue.poznan.pl

ORCID: 0000-0002-5838-8322

\section{Zuzanna Firkowska-Jakobsze}

University of Lodz, Faculty of Management, Lodz, Poland

e-mail: zuzanna.jakobsze@uni.lodz.pl

ORCID: 0000-0002-8646-6703

\section{Stanisław Hońko}

University of Szczecin, Institute of Economics and Finance, Szczecin, Poland e-mail: stanislaw.honko@usz.edu.pl

ORCID: 0000-0002-8726-2323

(C) 2019 Małgorzata Czerny, Zuzanna Firkowska-Jakobsze, Stanisław Hońko

This is an open access article distributed under the Creative Commons Attribution-NonCommercial-NoDerivs license (http://creativecommons.org/licenses/by-nc-nd/3.0/)

DOI: 10.15611/fins.2019.4.03

JEL Classification: M41

\begin{abstract}
The purpose of this article is to assess a comparability in the financial statements of entities from the Polish gaming industry. The article uses an unconventional approach to the analysis of comparability of financial statements, with particular emphasis on the business model of the entity. The overall conclusion is that Polish companies used similar accounting policies during the period under review regarding the methods of valuation of assets and liabilities. The scope of disclosures regarding impairment of assets does not allow for a full assessment of the premises underlying them. It is difficult to find out the criteria for qualifying costs for research and development, which are an important asset item. Deficiencies in disclosures are a common feature of the analyzed reports, which can be interpreted as a symptom of their comparability. The analyzed reports, despite the differences diagnosed, make possible to compare the financial situation and achievements of gaming companies.
\end{abstract}

Keywords: financial statements, comparability, video game industry, gaming companies. 


\section{Introduction}

Financial reports should communicate apropriate information about the entity to capital providers. The content of financial reports depends on a number of factors, including for example legal regulations. Undoubtedly, the entity's business model has a fundamental impact on the content of these reports. There are two approaches to the business model in the literature. From a narrow perspective, it is stated that a business model is simply a way of generating revenue for the entity. In the broad approach, the business model is understood as a way of generating value by a given entity (Michalak, Bek-Gaik, and Karwowski, 2018, pp. 11-12). The question therefore arises whether the financial reporting model is flexible enough to properly present the entity's business model? It is also understood that the model is not immutable. Accounting regulations, including IFRS, only to a small extent refer to the impact of the business model on the principles of preparing financial statements. IFRS 9 on financial instruments is currently an example of such regulations. Despite earlier announcements, IASB did not decide to define the business model at the level of Conceptual Framework. The explanations regarding the application of the 2018 Conceptual Framework (IASB, 2018) only state that IASB decided to use the term "business activities" rather than "business model". The explanation is hardly comprehensive, because the Board considered that the term "business model" is ambiguous and is used by many organisations with a range of different meanings (IASB, 2018, BC0.33). Michalak, Bek-Gaik and Karwowski argue that the business model does not currently play a significant role in the determination of accounting policy and presentation of information in the financial statements $(2018$, p. 71). Despite the lack of agreement on the essence of the business model and lack of legal regulations in this area, one can formulate the initial hypothesis that the financial statements of entities with a similar business model show some common features. However, assessing the similarity of these reports requires that one of the improving qualitative characteristics of financial statements (namely comparability) is met.

The purpose of this article is to assess comparability in the financial statements of entities from the computer games industry. The argument for choosing this market segment is its economic significance as well as initiating the publication of the WIG. GAMES index from March 2019.

According to Newzoo (2018) - a renowned global provider of games and e-sports analytics - the volume of the global videogame market was estimated at 134.9 billion USD at the end of 2018, which corresponds to a 10.9\% increase over the 2017 yearend value (121.7 billion USD). In 2018 very strong growth was observed in the console segment, which was estimated at 38.3 billion USD on 31 December 2018 (notable $y / y$ increase of $15.2 \%$ ) (2019). Long-term projections remain optimistic. The cumulative annual growth rate (CAGR) for the 2017-2021 period is estimated at $9.3 \%$, with a projected 2019 year-end value of 148.1 billion USD. In a report titled 
'Global Entertainment \& Media Outlook 2018-2022' PwC notes that consumers devote ever more time and resources to media and entertainment, with videogames currently ranking as the second most popular leisure activity. An argument for choosing companies in this industry is also a small number of studies on the accounting of units from the computer games industry. Therefore, in our opinion, this article at least partially supplements the existing research gap.

The structure of the article was subordinated to this goal, including a brief description of the computer games producers market, a literature review and an empirical part. This text provides the answer to the following research questions related to the reaserched computer game producers:

- Are there specific features of the financial statements?

- What is the structure of assets and liabilities?

- What elements determine the result on operating activities, net financial result and total income?

- Are there common elements of the accounting policy?

- Are the disclosures about the most significant assets/liabilities the richest in content?

\section{A literature review}

\subsection{Video game industry in the scientific literature}

There is a noticeable lack of studies devoted to financial reporting of enterprises operating in the gaming industry, which is quite surprising. The global video game streaming market is predicted to grow by $27 \%$ a year between 2018 and 2026, according to Zion Market Research, surging from about $\$ 800$ million in annual sales in 2017 to $\$ 6.9$ billion (Mohamed, 2019). It is becoming an important branch of industry and mass culture, forcing investments in technological and marketing innovations. The gaming industry generates demand for an increasing number of creative and qualified employees: designers, programmers, animators, sound engineers, screenwriters, and finally testers (Krok, 2016, p. 50). Some games are capable of altering basic cognitive skills, so not only stakeholders, game industry leaders and players, but also governmental officials and scientists may be interested in the game market. Thus, it is definitely a serious field of research.

The literature research shows that interests in the computer games market focus on the following areas: characteristic features of this industry, psychological and social aspects and the future of this industry (mostly in terms of new technologies and consumers).

In Poland, among others, E. Krok (2016) and M. Nowicki (2013) dealt with the characteristics of video game market. The conclusions of their analyses have been that companies operating on video game markets will develop unique operational 
strategies, which are absent in other areas of the economy. This will result in the creation of gaps in the economic and management science, which explanation will be worth scientific effort. Also, it is difficult to present other area of economy that would be economically equivalent to this industry, due to its specific, very high growth rate, constant development, and high resistance to the conditions of global macroeconomic environment (Nowicki, 2013, p. 381). Quite a similar opinion was expressed by Zackariasson and Wilson (Zackariasson and Wilson, 2010).

The potential of using computer games in education was noticed long time ago (Carenys, Moya, and Perramon, 2017; Green and Seitz, 2015; Mitchell and SavillSmith, 2004; Ritterfeld and Weber, 2006), as well as some psychological and social aspects of growing gaming industry, not always considered as welcomed (Granic, Lobel, and Engels, 2014; Kowert and Quandt, 2015; Shi, Renwick, Turner, and Kirsh, 2019). Also in Poland this psycho-social aspect of growing video game market is a subject of scientific researches (Prósinowski and Krzywdziński, 2016; Taper, 2011; Stasieńko, 2011).

Among the articles presenting a more economic approach to the topic, noteworthy are studies conducted by G. Clavio, P. Kraft and P. Pedersen (2009) dedicated to communication with consumers through video games, and by A. Marchand and T. Henning-Thurau (2013), about a value creation through video games, where authors notice that the video game industry with its oligopolic structure and indirect network effects between consumers and content and platform providers is closely linked to other entertainment industries such as motion pictures or social media and also, that the value of games depends on the technological infrastructure as well as customers and their expectations. There are also some papers about marketing (Heitmann and Tidten, 2011; Zackariasson and Wilson, 2012) or competitive advantage of this industry in different countries (Liu and Gao, 2011). The financial aspects of video game industry are surprisingly almost absent in the scholarly literature, except a few, scientific articles about its revenues (Chang, $\mathrm{Ku}$, and $\mathrm{Fu}$, 2013), business models and strategy research conducted by R. Lee (2013). Some attention was also paid to microtransactions in video game industry (Tomić, 2017), as a changing model of earning for video game publishers. There are no studies in the field of accounting, which makes a thesis of F. Alpert (2007) still valid that there remains a huge gap in knowledge about this industry presented by scientists, even if profits generated by this market are clearly noticeable and arouse an interest.

In summary, the understanding of video game industry in the scientific literature is still very limited and under-researched, given its large size and importance. An existing economic literature addresses several aspects, but has not been completed or integrated yet. 


\subsection{The comparability of financial statements in scientific literature}

The situation is different in the case of literature on comparability of financial statements. It is one of the main points of interest of financial accounting research, so the literature on the subject is abundant here. In the past, studies on financial statement comparability mainly used a comparison of financial statement inputs, concerned with the similarity of accounting rules in different countries or accounting systems (Nobes, 2001) or the equivalence of financial statement methods used by the firms (van der Tas, 1988) until De Franco, Kothari, and Verdi (2011) took a different approach, focusing on the output of the financial reporting process, such as earnings. They stated that the similarity in these financial reporting numbers did not necessarily mean that financial reporting practices were similar. Then Yip and Young (2012) proved that similar firms became more similar across countries after IFRS had been adopted in the country, and in contrast, no consistent results on the difference withincountry comparability were found. Kim, Kraft and Ryan (2013) conducted the analysis showing that the measures of comparability were positively associated with bond liquidity.

As rightly notes B. Pantić (2016), two main streams of research can be observed in contemporary literature: one is devoted to the comparability problems from the aspect of adoption of IFRS in different countries. Besides mentioned above study of Yip and Young (2012), in this area of research significant are studies conducted by Barth, Landsman, Lang, and Williams (2012), Cascino and Gassen (2015), Horton, Serafeim, and Serafeim (2013), DeFond et al. (2011), Brochet, Jagolinzer, and Riedl (2013). The second stream of research focuses on the determinants of comparability and events leading to a change in comparability. In this area, a study conducted by Land and Lang (2002) gives an evidence of accounting standards becoming more similar across countries over time. A study by Francis, Pinnuck, and Watanabe (2013) examines whether the style of audit is related to accounting comparability and whether companies audited by the same consultants display more comparable financial statements than those not audited by same auditors. Young and Zeng (2015) calculate the difference between the valuation error when peers are selected based on accounting data, and when peers are selected by industry.

In Polish literature there can be observed a trend of research focusing on comparability of financial statements as the quality feature of financial reporting (mainly usefullness). Significant are works by B. Bek-Gaik (2013), J. Błażyńska (2015), H. Buk (2011), J. Gierusz (2005, 2010), E. Walińska (2009, 2010), $\mathrm{K}$. Winiarska (1994), or P. Wójtowicz (2015). The conclusion of authors is common - a comparability of financial statements is one of the most important factors of quality of financial reports, mainly determining (along with understandability) their usefullness, although sometimes there are voices, that "a comparability was abandoned in favor of usefulness" (Błażyńska, 2012, p. 16). Similar opinion is 
expressed by Bratten, Choudhary, and Schipper (2013). Most authors argue though, i.e. Garstecki (2014), as well as Hirst and Hopkins (1998, p. 48), that the abandonment of comparability may in extreme cases be equal to resignation from the usefulness. The approach of this stream of studies in Polish literature is not different in conclusions than in similar studies in English, just based more on theory of accounting and its desirable qualities. Authors rank these qualitative features differently - for Rówińska (2013) the most important is reliability, while for Adamczyk (2012) reliability is equal with comparability (one conditions the other); a comparability is particularly emphasized also by Wierzbińska (2014), Wójcik-Jurkiewicz and Jurkiewicz (2014), who claim that a comparability as well as an integrity of financial statement are extremely important for its reliability, or Karmańska (2006), for who a comparability is the main condition of "decision usability" of financial statements. A comparability is also present in a model proposed by Wiatr (2013) to improve financial reporting's perfection, as a factor conditioning faithfulness and usefulness of financial information.

The issue of comparability is present in scientific literature on financial statements, their quality, informational role, etc., in a context of many sectors and branches. There were examined developers (Kalinowski, 2011), local government units (Adamczyk, 2012), fuel industry (Remlein, 2015), public finance sector (Kostrzewa, 2011), SME (Martyniuk, 2008; Gabrusewicz, 2008). These publications are not always dedicated solely to the comparability of financial reports, but it is an important part of their reflection. Similarly, papers in English examine a comparability of financial statements in a context of enviromental diversity (Edwards, Birkin, and Woodward, 2002) and cultural influences (Masca, 2012; Mukoro and Ojeka, 2011; Prescott and Vann, 2015; Zeff, 2007), stock prices about future earnings (Choi, Choi, and Myers, 2019), cost of equity capital (Imhof, Seavey, and Smith, 2017), fair value (Barlev and Haddad, 2007; Esquivel and Gornik-Tomaszewski, 2007), crash risk (Kim, Li, Liu, and Yu, 2016), information transfer (Wang, 2014), product market competition (Balakrishnan and Cohen, 2012), loan contracting (Fang, Li, Xin, and Zhang, 2012), etc. The authors look for some regularities between a subject of research and comparability of financial reports. Still, there is a lack of analysis of gaming industry and its financial reporting in a context of comparability. This gap is present both in Polish and English literature.

\section{Results of empirical research}

\subsection{A brief presentation of the researched companies}

Within this research, all the available game industry reports for the period 2018 were analyzed. The researched population embraces 5 game industry reports derived from the WIG.GAME. On 18 March 2019 the Warsaw Stock Exchange began publishing 
the WIG.GAMES index, basing on its specificity. Importantly, the number of companies, index participants will be constant, their qualification will take place basing on liquidity analysis, and the shares of the largest companies will be limited. Sector indexes do not meet such rules in which the classification of companies and their weights result from their participation in the WIG. Thanks to this, we will expand our index offer with indicators that may be the underlying instruments for futures contracts. The index composition as at 19 February 2019 (the percentage means the share in the index): CDPROJECT $-44.20 \%, 11 \mathrm{BIT}-27.84 \%$, TSGAMES $-13.38 \%$, PLAYWAY - 9.71\%, CIGAMES - $4.86 \%$.

CD PROJECT RED is a game development studio founded in 2002. The main area of activity are videogames. It develops and publishes video games for personal computers and video game consoles. The studio's flagship titles include The Witcher series of games and the upcoming futuristic AAA role-playing game - Cyberpunk 2077. CD PROJECT S.A. is the holding company of the CD PROJECT Capital Group which conducts its operations in two activity segments: CD PROJECT RED and GOG.com.

11 BIT is a developer of multiplatform games sold all around the world. The company operates in an independent model, dealing with each stage of creating games independently - from production through marketing to distribution in digital stores. The most famous games are: Anomaly and This War of Mine. In addition to game production, the group also publishes external games, and runs an online sales platform for games from other gamesrepublic.com producers. The main area of competence of this firm is the creation of video games, i.e. the product development process from concept creation to the ready-to-sell version. The company offers video games on many hardware platforms, including PC and Mac computers, desktop and mobile video game consoles, smartphones and tablets. The products are sold in almost $100 \%$ by digital distribution. The group's strategy also involves developing publishing competences as part of the 11 BIT publishing initiative (production and distribution of independent games produced by 11 BIT Studios S.A. or external developers from Poland and abroad). It offers independent developers financial, conceptual, technological and promotional support at every stage of game production and sale, also through the gamesrepublic.com platform. Spacecom was the first game released as part of the new 11 BIT publishing section in September 2014. In 2017 Beat Cop and Tower 57 premiered.

Ten Square Games S.A. is one of the largest mobile games producers and publishers in Poland (it has created over 250 games so far). It specializes in hobby games in a free-to-play model, earning on micropayments (for obtaining paid ingame functionalities) and advertising. Their games are offered on the most important mobile platforms - iOS and Android and through internet portals. The best-known projects are Let's Fish, with over 60 million unique players, and Fishing Clash currently the most popular fishing game in the world. The parent entity conducts 
development works related to new games. Subsidiaries focus on publishing smaller titles which aim to test new ideas on the market while generating revenues. The Group's strategy is based on the search and innovative combination of the most effective game models from the Free2Play segment with interesting thematic areas.

PlayWay S.A. is a Polish joint-stock company founded in 2011 and one of the largest companies in Poland creating video games for the most popular hardware platforms (PC/PS4/Xbox1/iOS/Android). The company currently has 44 development teams responsible for the creation of over 60 games. Activity on such a large scale is possible thanks to the unique formula of cooperation with the teams created by the company, giving them great freedom of action and independence, while maintaining the necessary quality control with full production, marketing and publishing support. PlayWay cooperates with experienced, large development studios and creators known in the industry, but it has also incubated young, aspiring teams. The company boasts global successes, among others, the Car Mechanic Simulator series created in cooperation with the most famous global luxury car manufacturers, such as Mercedes-Benz, Maserati, Bentley, Pagani, DeLorean. The company is also known for producing such games as Hard West (produced by CreativeForge Games S.A.), Farm Expert and The Way. PlayWay can also boast over 12 million downloads of its games on mobile platforms (including Car Mechanic Simulator 2014 Mobile, Diner Mania, Farm Fix, Truck Fix), and a record number of 5 successful crowdfunding actions. Their strategy involves creating a diversified portfolio of game titles to avoid the risk of becoming dependent on a single title, building and including new development teams in the Group, as well as working on new mobile games and console games.

CI Games is a worldwide publisher, developer and distributor of interactive entertainment, with operation offices in Warsaw, New York, and Amsterdam. The company and its subsidiaries have competences in all business areas of the video games market. The company acts as a producer, creating new titles in support of external partners. The studio in Warsaw specializes in the production of FPS video games. It is also a publisher of own games and licensed titles (creating a marketing strategy and selling through local distributors). The company has concluded contracts for the production and self-publishing of games with the owners of the most popular consoles, i.e. Sony and Microsoft. The company creates games for all key PlayStation, $\mathrm{Xbox}$ and PC platforms. Finally, CI Games is a distributor that sells products directly to retail chains and in digital distribution. Subsidiary - CI Games USA Inc. - is dedicated to direct sales support, among others on the American market. As a consequence of the combination of the above-mentioned areas of activity, the company can effectively control the production and distribution process of its games and licensed titles of other producers. The Group creates products based on its own and external IP. Key brands include Lords of the Fallen and Sniper Ghost Warrior. As of the date of publication of the Information Memorandum, Lords of the Fallen has already hit over 9,000,000 players around the world, and the Sniper Ghost Warrior 
titles have so far spread over a total of well over 7,000,000 copies sold. To maximize sales effectiveness and marketing potential, the company cooperates with international distributors operating on individual regional markets, who are also responsible for implementing promotional and marketing plans. The games of the company are available in the largest global digital distribution channels - Steam, PlayStation Store, Xbox Games Store and App Store, Google Store. In the case of digital games for PCs, the business of the company is expanded to include direct cooperation with the largest internet platforms, thanks to which it reaches a wide range of players around the world and enables the purchase of games in local currencies.

\subsection{Review of the content of financial statements of companies from the WIG.GAMES index}

This part of the text describes the results of the comparability analysis of the financial statements of the companies/capital groups described above. The study assumed that the activity of computer game producers required incurring significant costs of research and development works. In addition, the revenue recognition model was tested, as gaming companies sold their products to distributors, and in addition to games, they also benefitted from additional accessories, including virtual currencies or form advertisements. It is worth noting that in 2018, IFRS 15 was applied for the first time, which could affect the revenue recognition model of listed companies. A typical asset for gaming companies is game engines, that provide features from animation to artificial intelligence and are responsible for example for rendering graphics and collision detection. The comparability test was carried out using the author's checklist. The results of the analysis are presented in Tables 1-4.

Tables 1 and 2 contain information about selected features of the statement of comprehensive income of the analyzed companies. These results show a slightly higher share in current assets than non-current assets. Only one of the studied organisations (CI Games) has the opposite situation.

The highest amount of total sales revenues, sales revenues and total assets was achieved by CD Project. However, CD Project is in the middle of analyzed companies (21.55\% of non-current assets and $49.25 \%$ of current assets).

The company which has the lowest total sales revenues - CI Games, has the highest component of non-current asssets $(56.71 \%)$, but the lowest score of current assets $(13.68 \%)$.

All companies apply historical cost except financial instruments.

None of the entities found a significant impact of the implementation of IFRS 15 on the revenue recognition principles, but two companies claim that the revenue recognition principles are more specific (detailed) comparing to IFRS 15. In addition, only one of the analyzed companies discloses the principles of recognizing revenues from the sale of virtual currencies and the principles of recognizing revenue from transactions with the right of return. 


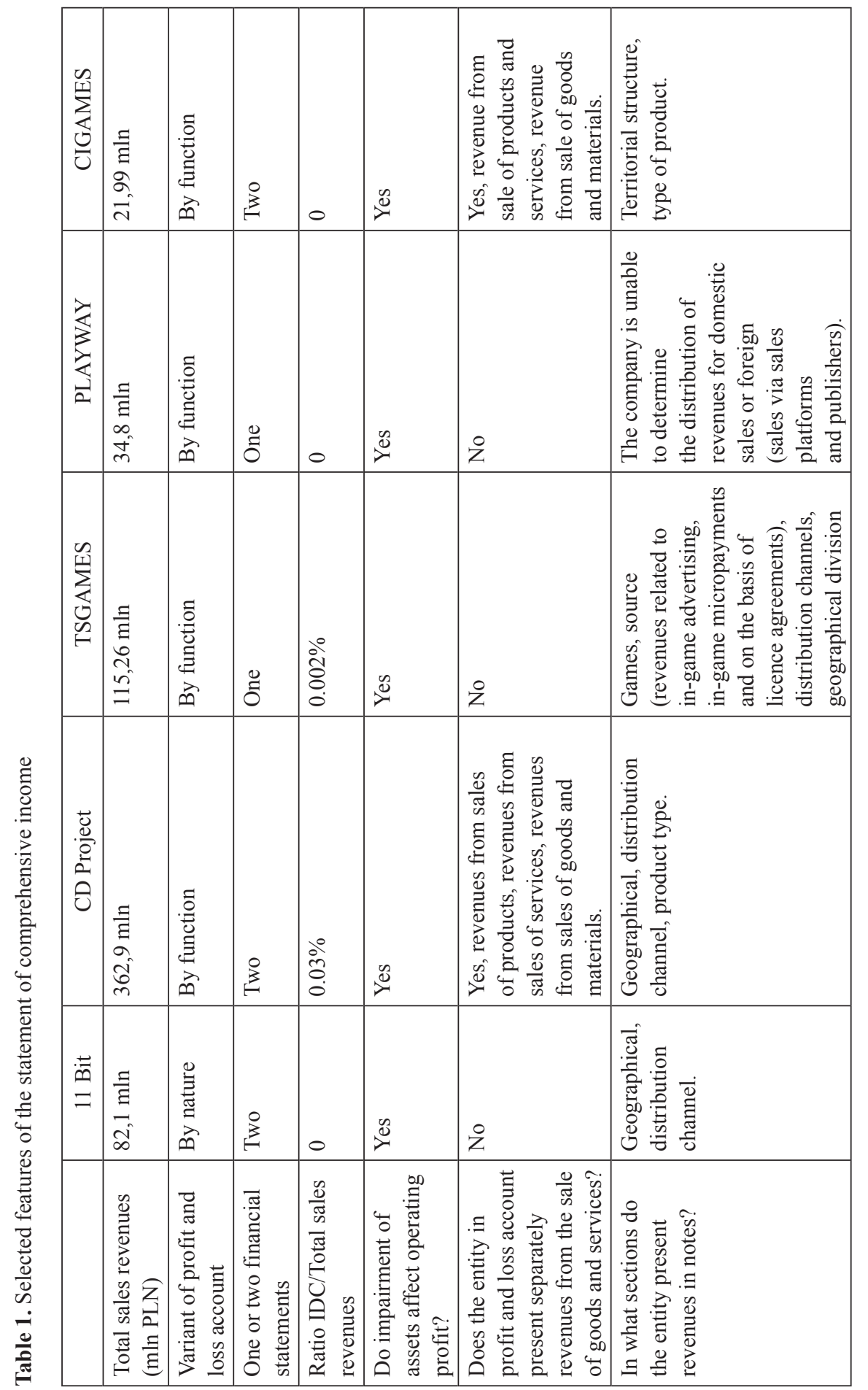

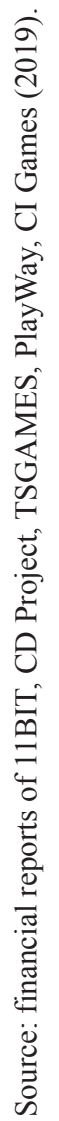




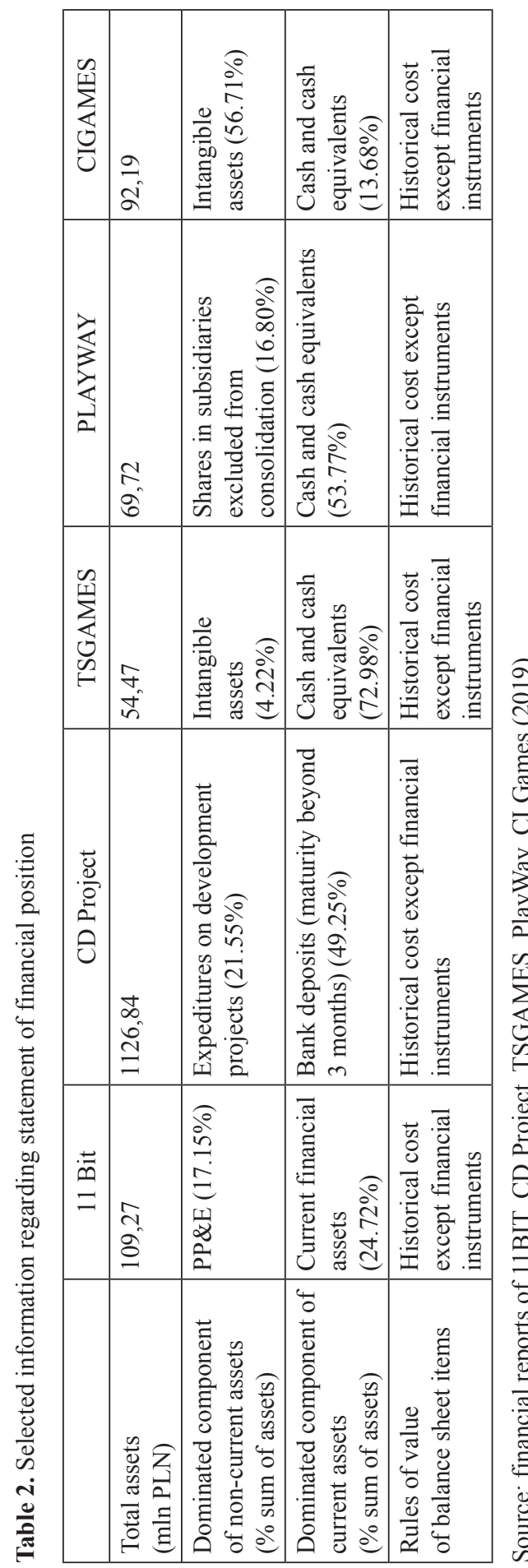

\begin{tabular}{|c|c|c|c|c|}
\hline 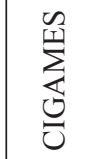 & z & $\stackrel{0}{2}$ & $\stackrel{0}{z}$ & z \\
\hline 究 & $\stackrel{0}{z}$ & $\stackrel{0}{z}$ & $\stackrel{\circ}{z}$ & $\stackrel{\circ}{z}$ \\
\hline 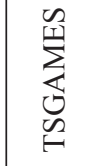 & ż & z & ż & $\stackrel{\circ}{z}$ \\
\hline 己 & $\stackrel{0}{z}$ & $\stackrel{\infty}{\infty}$ & $\triangleq$ & $\triangleq$ \\
\hline $\begin{array}{l}\text { 駋 } \\
=\end{array}$ & Z & 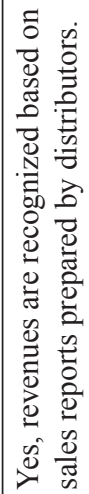 & Zे & z \\
\hline & 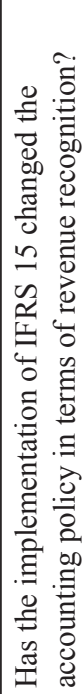 & 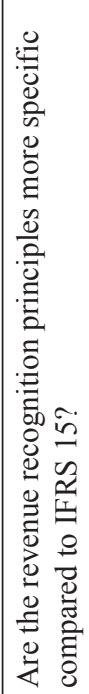 & 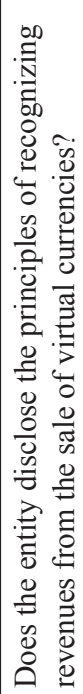 & 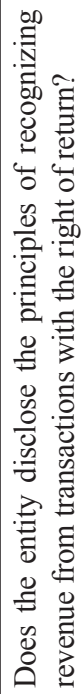 \\
\hline
\end{tabular}

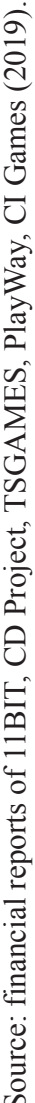




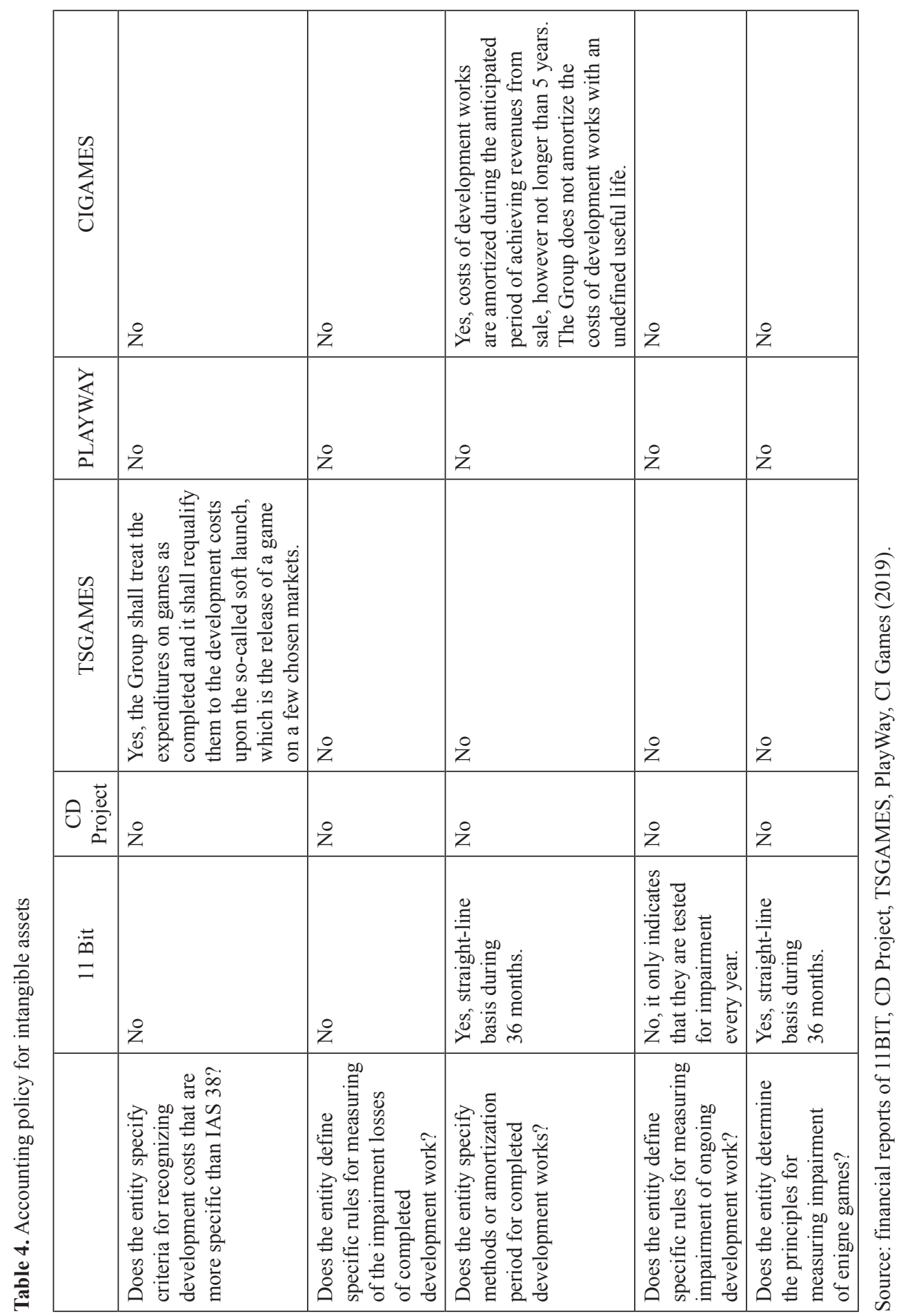


The gaming companies used similar accounting policies during the period under review. The scope of disclosures regarding impairment of assets also does not allow for a full assessment of the premises underlying them. It is also difficult to find out what the criteria for qualifying costs for research and development are and what an important asset item for them is.

\section{Conclusions}

The issue of comparability underlies the implementation of IFRS, which were to facilitate the global flow of capital. Conceptual framework explain comparability as qualitative characteristic of finacial statements that enables users to identify and understand similarities in, and differences among, items (IASB, 2018: 2.23, 2.25). Comparability has two aspects - comparability in reporting by one entity over time and between entities (IASB, 2018: 2.27) Information about an entity is more useful when it can be compared with similar information about other entities and with similar information about the same entity for another period or date. (IASB, 2018: 2.24). IASB is promoting comparability of financial statements in many ways. The starting point is that better understanding of the essence of standards by preparers is conducive to achieving comparability. That is why there are more and more illustrative examples in new standards. FASB undertakes similar activities. The American Board emphasizes that success requires the cooperation of many standards setters. The challenge is difficult because "different business cultures, different regulatory environments, different financial reporting objectives, and different legal systems can make it difficult for standard setters around the world to agree on the same accounting alternative" (www.fasb.org).

Many users of financial statements as well as some accountants expect a template presentation of financial information which is the same for every company, regardless of its business model or applied accounting policy. But IFRS are principle-based standards with extensive use of the expert approach and professional judgement, which undoubtedly affects the comparability of information. Restoring comparability in this sense seems currently impossible. A. Tarca, a member of IASB, formulates the following question for researchers dealing with the comparability of financial information: Does the use of options (in accounting policy - the authors' annotation) reduce the quality of information because comparability is reduced or does the use of an option, or the judgements made in applying a policy, reflect economic fundamentals and thus provide useful information for investors? (Tarca, 2019). In our opinion, the existence of many options does not automatically reduce the comparability of information. Comparability is primarily influenced by the quality of disclosures.

Many studies consider similar accounting policies for entities with a similar business model as a measure of comparability. Another measure is the similar scope of disclosures related to similar economic phenomena. This article analyzes selected 
fragments of accounting policy and the scope of disclosures of companies from the computer games industry.

The article uses the expert method, which consisted in focusing on the most significant items of the numerical and descriptive parts of the financial statements. The overall conclusion of this analysis is that gaming companies used similar accounting policies during the period under review. None of the entities found a significant impact of the implementation of IFRS 15 on the revenue recognition principles. However, the justification for not having this effect is quite laconic and does not allow a full understanding of revenue recognition principles and the scale of estimation of expected remuneration. The analyzed entities inform too briefly about the methods of valuation of assets and liabilities. There is a fairly good agreement in this area. The scope of disclosures regarding the impairment of assets also does not allow for a full assessment of the premises underlying them. It is also difficult to find out what are the criteria for qualifying costs for research and development are what an important asset item is. Deficiencies in disclosures are a common feature of the analyzed reports, which paradoxically can be interpreted as a symptom of their comparability. In our opinion, the analyzed financial statements, despite the differences diagnosed, make possible to compare the financial situation and achievements of the analyzed gaming companies.

We are aware of the limitations associated with the study. It concerns one period, a small research sample, which included five companies belonging to the WIG.GAMES index. Taking into account the relatively short period of operation of this index, it was limited to analyzing the financial statements for 2018 from one industry. In next studies, it is worth analyzing subsequent groups of entities with a similar business model. It would also be interesting to study the comparability of information of companies using IFRS with a similar business model, but coming from different countries.

\section{References}

Adamczyk, M. (2012). Jakość informacji finansowych jako podstawa wiarygodności sprawozdań finansowych jednostek samorządu terytorialnego. Finanse, Rynki Finansowe, Ubezpieczenia, (53), 393-404.

Alpert, F. (2007). The entertainment software industry: Suddenly huge, little understood. Asia-Pacific Journal of Marketing and Logistics, 19(1), 87-100.

Balakrishnan, K., and Cohen, D. A. (2012). Product market competition and financial accounting misreporting. Retrieved from http://web-docs.stern.nyu.edu/old_web/emplibrary/BC_March_09.pdf

Barlev, B., Haddad, J. (2007). Harmonization, comparability, and fair value accounting. Journal of Accounting, Auditing and Finance, 22(3), 493-509.

Barth, M., Landsman, W., Lang, M., and Williams, C. (2012). Are IFRS-based and US GAAP-based accounting amounts comparable? Journal of Accounting and Economics, (54), 68-93.

Bek-Gaik, B. (2013). Sprawozdawczy wymiar rachunku wyników w warunkach globalnego rynku. Łódź: Wydawnictwo Uniwersytetu Łódzkiego. 
Błażyńska, J. (2012). Standaryzacja zasad rachunkowości finansowej a perspektywy rozwoju rachunkowości. In W. Gabrusewicz, \& J. Samelak (Eds.), Obszary badawcze współczesnej rachunkowości, Zeszyty Naukowe, (233).

Błażyńska, J. (2015). Użyteczność informacji finansowych sprawozdań finansowych, Poznań: Wydawnictwo Uniwersytetu Ekonomicznego w Poznaniu.

Bratten, B., Choudhary, P., and Schipper, K. (2013). Evidence that market participants assess recognized and disclosed items similarly when reliability is not an issue, The Accounting Review, 88(4), 1179-1210.

Brochet, F., Jagolinzer, A. D., and Riedl, E. (2013). Mandatory IFRS adoption and financial statement comparability. Contemporary Accounting Research, (30), 1373-1400.

Buk, H. (2011). Sprawozdanie z całkowitych dochodów w świetle koncepcji zachowania kapitału. In B. Micherda (Ed.), Sprawozdawczość i rewizja finansowa - kierunki zmian. Kraków: Wydawnictwo Uniwersytetu Ekonomicznego w Krakowie.

Carenys, J., Moya, S., and Perramon, J. (2017). Is it worth it to consider videogames in accounting education? A comparison of a simulation and a videogame in attributes, motivation and learning outcomes. Revista de Contabilidad - Spanish Accounting Review, 20(2), 118-130.

Cascino, S., and Gassen, J. (2015). What drives the comparability effect of mandatory IFRS adoption? Review of Accounting Studies, (20), 242-282.

Chang, T-S., Ku, C-Y., and Fu, H-P. (2013). Grey theory analysis of online population and online game industry revenue in Taiwan. Technological Forecasting and Social Change, 80(1), 175-185.

Choi, J-H., Choi, S., and Myers, L. (2019). Financial statement comparability and the informativeness of stock prices about future earnings. Contemporary Accounting Research, 36(1), 389-417.

Clavio, G., Kraft, P., and Pedersen, P. (2009). Communicating with consumers through video games: An analysis of brand development within the video gaming segment of the sports industry. International Journal of Sports Marketing and Sponsorship, 10(2), 39-52.

DeFond, M., Hu, X., Hung, M., and Li, S. (2011). The impact of mandatory IFRS adoption on foreign mutual fund ownership: The role of comparability. Journal of Accounting and Economics, (51), 240-258.

De Franco, G., Kothari, S. P., and Verdi, R. S. (2011). The benefits of financial statement comparability. Journal of Accounting Research, (49), 895-931.

Edwards, P., Birkin, F., and Woodward, D. (2002). Financial comparability and environmental diversity: An international context. Business Strategy and the Environment, 11(6), 343-359.

Esquivel, O., and Gornik-Tomaszewski, S. (2007). Fair value measurements in impairment testing: How SFAS No. 157 increases consistency and comparability. Review of Business, 27(4), 20-21.

Fang, X., Li, Y., Xin, B., and Zhang, W. (2012). Accounting comparability and loan contracting. Retrieved from https://pdfs.semanticscholar.org/a30c/ed5766388d6ae83b123e3183d535a36598ec. pdf

FASB. (2019). Retrived from https://www.fasb.org/jsp/FASB/Page/SectionPage\&cid=1176156245663

Financial Accounting Standards Board. (2019). Retrived from http://www.fasb.org

Financial Report. (2019). 11BIT. Retrived from http://www.ir.11bitstudios.com/financial-reports

Financial Report. (2019). CD Project. Retrived from https://www.cdprojekt.com/en/investors/financial-summary-report/

Financial Report. (2019). CI Games. Retrived from http://cigames.com/relacje-investorskie/

Financial Report. (2019). PlayWay. Retrived from https://www.playway.com/akcje/roczne

Financial Report. (2019). TS GAMES. Retrived from https://tensquaregames.com/investors/

Francis, J. R., Pinnuck, M. L., and Watanabe, O. (2013). Auditor style and financial statement comparability. The Accounting Review, 89(2), 605-633.

Gabrusewicz, T. (2008). Próba syntetycznej prezentacji wyników testu przydatności Międzynarodowego Standardu Sprawozdawczości Finansowej dla Małych i Średnich Przedsiębiorstw. Zeszyty Teoretyczne Rachunkowości, (47), 41-48. 
Garstecki, D. (2014). Porównywalność a przydatność sprawozdań finansowych. Analiza w ujęciu metodologii K.R.Poppera. Studia Oeconomica Posnaniensia, 2(4), 7-22.

Gierusz, J. (2005). Koszty i przychody w świetle nadrzędnych zasad rachunkowości. Gdańsk: ODDK.

Gierusz, J. (2010). Ocena przygotowanego przez IASB i FASB projektu sprawozdania finansowego. Zeszyty Teoretyczne Rachunkowości, 56(112), 49-58.

Green, C., and Seitz, A. (2015). The impacts of video games on cognition (and how the government can guide the industry). Policy Insights from the Behavioral and Brain Sciences, 2(1), 101-110.

Granic, I., Lobel, A., and Engels, R. (2014). The benefits of playing video games. American Psychologist, 69(1), 66-78

Heitmann, M., and Tidten, K. (2011). New business models for the computer gaming industry: Selling an adventure. Business. In M. M. Cruz-Cunha, V. H. Varvalho, \& P. Tavares (Eds.), Technological, and social dimensions of computer games: Multidisciplinary developments. Retrieved fom https:// www.igi-global.com/chapter/new-business-models-computer-gaming/53941

Hirst, D. E., and Hopkins, P. E. (1998). Comprehensive income reporting and analysts' valuation judgments. Journal of Accounting Research, (36), 47-75.

Horton, J., Serafeim, G., and Serafeim, I. (2013). Does mandatory IFRS adoption improve the information environment? Contemporary Accounting Research, (30), 388-423.

IASB Conceptual Framework. (2018). Retrived from https://www.iasplus.com/en/standards/other/ framework

Imhof, M. J., Seavey, S. E., and Smith, D. B. (2017). Comparability and cost of equity capital. Accounting Horizons, 31(2), 125-138.

Kalinowski, J. (2011). Porównywalność sprawozdań finansowych firm deweloperskich na tle krajowych i międzynarodowych regulacji rachunkowości. Zeszyty Teoretyczne Rachunkowości, (60), 145-168.

Karmańska, A. (2006). Granice dążenia do dokładności informacyjnej sprawozdania finansowego na przykładzie odwracania dyskonta. Zeszyty Teoretyczne Rachunkowości, (32), 118-140.

Kim, S., Kraft, P., and Ryan, S. (2013). Financial statement comparability and credit risk. Review of Accounting Studies, (18), 783-823.

Kim, J-B., Li, L., Liu, L., and Yu, Y. (2016). Financial statement comparability and expected crash risk. Journal of Accounting and Economics, (61), 294-312.

Kostrzewa, T. (2011). Wdrożenie skonsolidowanego sprawozdania finansowego sektora finansów publicznych w Polsce. Finanse, Rynki Finansowe, Ubezpieczenia, (41), 595-605.

Kowert, R., and Quandt, T. (2015). The video game debate: Unravelling the physical, social, and psychological effects of video games. Abington: Routledge.

Krok, E. (2016). Rynek gier video i jego uczestnicy. Studia Informatica Pomerania, 2(40), 49-60.

Land, J., and Lang, M. H. (2002). Empirical evidence on the evolution of international earnings. The Accounting Review, (77), 115-133.

Lee, R. (2013). Business models and strategies in the video game industry: An analysis of Activision-Blizzard and Electronic Arts. Retrieved from https://dspace.mit.edu/handle/1721.1/81088

Liu, F., and Gao, Y. (2011). Competitive advantage in the online game industry in Taiwan. Journal of Strategy and Management, 4(2), 136-154.

Marchand, A., and Henning-Thurau, T. (2013). Value creation in the video game industry: Industry economics, consumer benefits, and research opportunities. Journal of Interactive Marketing, 27(3), 141-157.

Martyniuk, T. (2008). Czy globalna standaryzacja sprawozdawczości finansowej dla sektora małych i średnich przedsiębiorstw? Zeszyty Teoretyczne Rachunkowości, (44), 135-145.

Masca, E. (2012). Influence of cultural factors in adoption of the IFRS for SMEs. Procedia Economics and Finance, (3), 567-575. 
Michalak, J., Bek-Gaik, B., and Karwowski, M. (2018). Model biznesu jako wyzwanie dla rachunkowości. Łódź: Wydawnictwo Uniwersytetu Łódzkiego.

Mitchell, A., and Savill-Smith, C. (2004). The use of video and video games for learning. London: Learning and Skills Development Agency.

Mohamed, T. (2019). 5 ways the video-game industry will change in the next decade. Retrieved from https://markets.businessinsider.com/news/stocks/5-ways-the-video-game-industry-will-changein-the-next-decade-2019-7-1028394586\#streaming-gameplay 1

Mukoro, D. O., and Ojeka, S. (2011). The challenge of culture to International Financial Reporting Standards (IFRS) convergence. Interdisciplinary Journal of Conemporary Resarch in Business, 2(12), 914-924.

Newzoo. (2018). Cuts global games forecast for 2018 to $\$ 134.9$ billion; Lower mobile growth partially offset by very strong growth in console segment. Retrieved from https://newzoo.com/insights/articles/newzoo-cuts-global-games-forecast-for-2018-to-134-9-billion/

Nobes, C. (2001). GAAP 2001. A survey of national accounting rules benchmarked against international accounting standards. International Forum on Accountancy Development (IFAD).

Nowicki, M. (2011). Rynek gier w Polsce i na świecie. Raport Game Industry Trends. Nonoobs.pl.

Nowicki, M. (2013). Charakterystyka i wybrane mechanizmy finansowania sektora gier komputerowych - na świecie i w Polsce. Zarzqdzanie i Finanse, 1(4), 363-382.

Pantić, B. (2016). Comparability of financial reports: A literature review of most recent studies (Working Paper 17 (E)). Graduate School of Management, St. Petersburg State University.

Perspectives from the global entertainment \& media outlook 2018-2022. Retrieved from www.pwc.

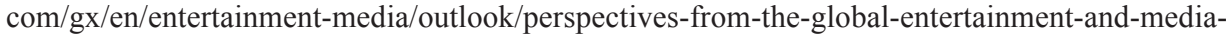
outlook-2018-2022.pdf

Prescott, G. L., and Vann, C. E. (2015). The effects of national culture on financial statement comparability: A survey of research findings. The Journal of Corporate Accounting \& Finance, 26(6), 37-45.

Prósinowski, P., and Krzywdziński, P. (2016). Gry wideo a postawa twórcza: potencjat i narracja zagrożeń. Ars Educandi, (13).

Remlein, M. (2015). Finansyzacja i jej skutki w sprawozdaniu finansowym polskich spółek giełdowych branży paliwowej. Zeszyty Teoretyczne Rachunkowości, (82), 129-140.

Ritterfeld, U., and Weber, R. (2006). Video Games for Entertainment and Education. In P. Vorderer \& J. Bryant (Eds.), Playing video games: Motives, responses, and consequences (pp. 399-413). Mahwah, NJ, US: Lawrence Erlbaum Associates Publishers.

Rówińska, M. (2013). Cechy jakościowe sprawozdania finansowego jednostek gospodarczych. Finanse, Rynki Finansowe, Ubezpieczenia, (58), 375-382.

Shi, J., Renwick, R., Turner, N. E., and Kirsh, B. (2019). Understanding the lives of problem gamers: The meaning, purpose, and influences of video gaming. Computers in Human Behavior, (97), 291-303.

Stasieńko, J. (2011). Gry komputerowe - jestem na ,tak”, jestem na „nie”. Zagrożenia, szanse i wyzwania rozrywki komputerowej. Wrocław: Dolnośląska Szkoła Wyższa.

Taper, A. (2011). Gry MMORPG - cechy, możliwości, zagrożenia. Media i Społeczeństwo, (1), 180-193.

Tarca, A. (2019). The IASB and comparability of international financial reporting: Implications of the research evidence. Retrieved from https:/www.wu.ac.at/fileadmin/wu/o/eufin2019/The IASB and_comparability_of_international_financial_reporting_-_Implications_of_the_research_evidence.pdf

Tas van der, L. G. (1988). Measuring harmonization of financial reporting practice. Accounting and Business Research, 18(70), 157-169.

Tomić, N. (2017). Effects of micro-transactions on video game industry. Megatrend Revija-Magatrend Review, 14(3), 239-258. 
Walińska, E. (2009). Bilans jako fundament sprawozdawczości finansowej, Warszawa: Oficyna Wydawnicza Wolters Kluwer Business.

Walińska, E. (2010). Bilans - propozycje nowej formuły sprawozdawczej. Zeszyty Teoretyczne Rachunkowości, 56(112), 267-282.

Wang, C. (2014). Accounting standards harmonization and financial statement comparability: Evidence from transnational information transfer. Journal of Accounting Research, 52(4), 955-992.

Wiatr, M. (2013). Koncepcja bilansu wedtug teorii Wilhelma Osbahra jako kierunku doskonalenia sprawozdawczości finansowej-propozycja modelu. Łódź: Wydawnictwo Uniwersytetu Łódzkiego.

Wierzbińska, Z. (2014). Wycena aktywów i pasywów a oczekiwania informacyjne użytkowników sprawozdań finansowych. Studia Oeconomica Posnaniensia, 2(4), 151-165.

Winiarska, K. (1994). Rachunek kosztów i wyników w zarządzaniu jednostkami gospodarczymi. Rozprawy i Studia Uniwersytetu Szczecińskiego, CCXXXIX(165).

Wójcik-Jurkiewicz, M., Jurkiewicz, R. (2014). Kierunki zmian w zakresie wiarygodności sprawozdań finansowych. Studia Ekonomiczne, (164), 168-175.

Wójtowicz, T. (2015). Aspekty praktyczne użyteczności sprawozdań finansowych. Zeszyty Teoretyczne Rachunkowości, 82(138), 151-166.

Yip, R., Young, D. (2012). Does mandatory IFRS adoption improve information comparability? The Accounting Review, (87), 1767-1789.

Young, S., and Zeng, Y. (2015). Accounting comparability and the accuracy of peer-based valuation models. The Accounting Review, 90(6), 2571-2601.

Zackariasson, P., and Wilson, T. (2010). Paradigm shifts in the video game industry. Competitiveness Review, 20(2), 139-151.

Zackariasson, P., and Wilson, T. (2012). The video game industry: Formation, present state, and future. Abington: Routledge.

Zeff, S. (2007). Some obstacles to global financial reporting comparability and convergence at a high level of quality. The British Accounting Review, (39), 290-302.

\section{PORÓWNYWALNOŚĆ SPRAWOZDAŃ FINANSOWYCH SPÓEEK BRANŻY GAMINGOWEJ}

Streszczenie: Celem artykułu jest ocena porównywalności sprawozdań finansowych polskich spółek gamingowych. Zastosowano nieszablonowe podejście do analizy porównywalności sprawozdań finansowych, uwzględniające przede wszystkim model biznesowy danej jednostki, koncentrując się na najważniejszych pozycjach sprawozdania finansowego. Przeprowadzona analiza pozwala stwierdzić, że polskie spółki w tej branży stosują w badanym okresie podobne zasady rachunkowości, bardzo ogólnie informując o metodach wyceny aktywów i pasywów, a zakres ujawnień dotyczących utraty wartości aktywów nie pozwala na pełną ocenę przesłanek leżących u ich podstaw. Trudno ustalić, jakie są kryteria kwalifikacji kosztów badań i rozwoju, będących w tej branży ważną pozycją aktywów. Braki w ujawnieniach są częstą cechą analizowanych raportów, co paradoksalnie można interpretować jako jeden z przejawów ich zgodności Mimo zdiagnozowanych różnic umożliwiają one porównanie sytuacji finansowej i osiągnięć spółek gamingowych.

Słowa kluczowe: sprawozdania finansowe, porównywalność, rynek gier, branża gamingowa. 